\title{
PENYERAHAN GIGI MANUSIA SEBAGAI BAHAN BIOLOGIS TERSIMPAN DALAM PENDIDIKAN DAN PENELITIAN KEDOKTERAN GIGI
}

\author{
Anggra Yudha Ramadianto \\ Staf Pengajar Akademi Perekam Medis dan Informatika Kesehatan Bandung \\ e-mail: anggra.bigcat@gmail.com
}

\begin{abstract}
Abstrak-Sebagian besar sumbangan ilmu kesehatan merupakan hasil penelitian dan penerapannya. Bahan biologis yang berasal dari manusia sejak abad ke-19 telah dimanfaatkan dalam jumlah besar untuk pengajaran dan penelitian kesehatan. Pendidikan kedokteran gigi menggunakan Bahan Biologis Tersimpan (BBT) berupa gigi-gigi manusia untuk kepentingan pendidikan dan penelitian. Pada praktek di lapangan terjadi pelanggaran terhadap hak otonomi dan hak milik dari pasien sebagai pemilik organ tubuh berupa gigi-gigi asli yang digunakan di dalam pendidikan dan penelitian kedokteran gigi. Tujuan penelitian ini adalah untuk mengetahui dan memahami praktek penggunaan Bahan Biologis Tersimpan dalam pendidikan dan penelitian kedokteran gigi, dan aspek kepemilikan Bahan Biologis Tersimpan untuk kepentingan pendidikan dan penelitian kedokteran gigi dengan pemiliknya, serta pengaturan hukum di masa yang akan datang terhadap penggunaan Bahan Biologis Tersimpan tanpa persetujuan pemiliknya. Hasil penelitian menunjukkan bahwa pelaksanaan prosedur pengumpulan gigi asli belum sesuai dengan Suplemen I Pedoman Etik Pemanfaatan BBT dan peraturan perundang-undangan yang berlaku tidak adanya kejelasan Persetujuan Setelah Penjelasan (PSP) mengenai pemanfaatan gigi-gigi tersebut sebagai BBT dan adanya komersialisasi organ tubuh. BBT gigi asli merupakan hak milik pasien sehingga hak milik pasien atas BBT gigi asli tersebut harus dilindungi oleh hukum. Bahwa hak milik pasien atas BBT gigi asli tersebut dilindungi oleh gugat Revindicatie yang diatur di dalam Pasal 574 KUH Perdata. Pemindahtanganan hak milik BBT gigi asli kepada pihak lain dapat dilakukan dengan cara penyerahan (levering). Dua pengaturan hukum di masa yang akan datang yang dapat dilakukan terkait penggunaan bahan biologis tersimpan tanpa persetujuan pemiliknya adalah berupa peraturan hukum mengenai pewasiatan organ tubuh jenazah untuk dimanfaatkan sebagai BBT dan peraturan hukum mengenai kewajiban pelaksanaan Persetujuan Setelah Penjelasan (PSP) dalam pemanfaatan organ tubuh manusia sebagai BBT.
\end{abstract}

Kata Kunci: Gigi Manusia, Bahan Biologis Tersimpan, Pendidikan Kedokteran Gigi, Penelitian Biomedis.

Abstract-Most healthcare donations are the result of its research and application.
Biological materials derived from humans since the 19th century have been exploited in
large quantities for teaching and health research. Dentistry education uses Stored
Biological Material (BBT) in the form of human teeth for educational and research
purposes. On the field practice, there is a violation of the autonomy and property rights
of the patient as the owner of the organs in the form of the original teeth used in the
education and research of dentistry. The purpose of this study is to know and understand
the practice of the use of Biological Material Stored in dental education and research,
and ownership of Biological Material Stored for educational and dental research
interests with its owner, as well as future legal arrangements against the use of
Biological Material Stored without the approval of the owner. The results of the study
indicate that the implementation of the original tooth collection procedure is not in 
accordance with the Supplement I of the BBT Utilization Ethics Guidelines and the applicable legislation in the absence of clarity of Approval After Explanation (PSP) regarding the utilization of these teeth as $B B T$ and the existence of organ commercialization. The original tooth $B B T$ is the property of the patient so that the patient's right to the original dental BBT must be protected by law. That the patient's right to BBT original tooth is protected by Revindicatie's lawsuit as set forth in Article 574 of the Civil Code. The transfer of the original BBT dental rights to another party can be done by levering. Two future legal arrangements that may be made regarding the use of biologically stored material without the consent of the owner are in the form of a legal regulation concerning the body's organs to be used as BBT and the legal regulation concerning the obligation of the implementation of the Approval After Explanation (PSP) in the utilization of human organs as BBT.

Keywords: Human Teeth, Stored Biological Material, Dental Education, Biomedical Research.

\section{A. PENDAHULUAN}

Fenomena penggunaan gigi-gigi manusia dalam pendidikan kedokteran gigi sudah seringkali menjadi pembahasan terkait aspek etika dalam eksperimen yang melibatkan manusia. Hal tersebut diperoleh dari adanya fakta berupa penggunaan gigi-gigi manusia untuk prosedur restoratif, pembuatan mahkota dan jembatan (dental crowns) untuk alat-alat prostetik, praktikum mahasiswa di laboratorium pra-klinik, dan penelitian-penelitian di bidangbidang kedokteran gigi (Silvia Helena, 2012).

Gigi-gigi yang digunakan oleh sebagian besar institusi pendidikan tidak memiliki asal-usul yang jelas. Sebagian besar pengajar hanya memberikan daftar gigi-gigi yang dibutuhkan dan bagaimana pelaksanaan teknis mendapatkan gigi tersebut diserahkan kepada mahasiswa. Sebagian besar mahasiswa tidak menerima panduan mengenai implikasi etik dan legalitas dari proses pengumpulan gigi tersebut dan para pengajar tidak menanyakan pula darimana asal gigi-gigi yang telah dikumpulkan sehingga proses pengumpulan dilakukan dengan cara yang tidak mengindahkan aspek etika dan aspek legal. Biasanya, gigi-gigi tersebut dibeli oleh para mahasiswa dari pemakaman, klinik-klinik pribadi, dan bahkan dari rekanrekannya (Elaine, 2014).

Pengumpulan gigi-gigi manusia untuk keperluan praktikum dalam 
pendidikan kedokteran gigi di dokter gigi adalah gigi yang Indonesia sudah menjadi 'tradisi'. berlubang besar atau sudah hancur, Gigi-gigi yang dikumpulkan bukanlah sehingga gigi-gigi tersebut tidak gigi yang sudah rusak atau bolong besar tapi gigi yang memiliki kondisi anatomis yang masih utuh. Praktikum menggunakan gigi-gigi manusia asli ini sangat penting dilakukan oleh para mahasiswa untuk mendapatkan pengalaman nyata pada saat berlatih melakukan pengeboran dan penambalan gigi. Oleh karena alasan tersebut penggunaan gigi-gigi asli ini tidak dapat digantikan dengan gigigigi tiruan dan juga tidak dapat dilakukan pada gigi-gigi yang masih menempel pada manusia hidup untuk menghindari risiko terjadinya kesalahan dalam pengeboran gigi. Selain itu, mahasiswa kedokteran gigi belum dianggap sebagai dokter gigi sehingga mereka belum memiliki kewenangan untuk melakukan intervensi langsung kepada manusia.

Permasalahan akan timbul pada saat pengumpulan gigi yang ternyata tidak semudah yang dibayangkan. Mengumpulkan gigi-gigi asli dengan kondisi anatomis yang masih utuh bukanlah perkara mudah karena 70$80 \%$ gigi-gigi yang dicabut oleh memenuhi syarat untuk digunakan dalam kegiatan praktikum.

Adanya kebutuhan untuk mengumpulkan gigi-gigi asli yang masih bagus ini akhirnya membuat mahasiswa harus mencari ke praktekpraktek dokter gigi. Bahkan ketika praktek-praktek dokter gigi sudah tidak dapat memenuhi kebutuhan tersebut, mahasiswa akan mendatangi penjaga kamar jenazah sambil memberikan uang rokok untuk mencabut gigi-gigi jenazah yang tidak ada sanak keluarganya atau bahkan mendatangi penjaga makam untuk melucuti gigi-gigi jenazah yang telah dikebumikan.

Setiap mahasiswa memerlukan 32 gigi asli untuk praktikum dan itu bukanlah jumlah yang kecil apabila dikalikan dengan jumlah mahasiswamahasiswa lain yang ikut mencari. Adanya permintaan yang cukup besar mengakibatkan gigi-gigi asli ini dikomersialisasikan sehingga mahasiswa-mahasiswa tersebut harus rela membayar uang sebesar Rp. 
10.000-Rp. 50.000 untuk harga sebuah gigi (Gustaf Kuno, 2015).

\section{B. HASIL DAN PEMBAHASAN}

\section{Aspek Kepemilikan Bahan} Biologis Tersimpan Untuk Kepentingan Pendidikan Dan Penelitian Kedokteran Gigi

\section{Dengan Pemiliknya}

BBT yang telah mendapatkan persetujuan dari sumber BBT dikumpulkan dan dikelola oleh lembaga kesehatan dan lembaga penelitian untuk kemudian digunakan dalam pendidikan atau penelitian di bidang kesehatan. Adapun seperti dinyatakan di dalam pedoman etik pemanfaatan BBT bahwa semua BBT yang dikumpulkan untuk penelitian kesehatan adalah milik lembaga pelayanan atau penelitian.

Agar BBT tersebut dapat menjadi milik lembaga pelayanan atau penelitian dibutuhkan adanya pengalihan hak milik. Untuk memahami bagaimana pengalihan hak milik BBT dari pasien kepada lembaga pelayanan atau penelitian, perlu diketahui terlebih dahulu bagaimana aspek kepemilikan BBT dengan sumber BBT (pemiliknya). Berbicara mengenai aspek kepemilikan maka hal tersebut tidak dapat dilepaskan dari permasalahan hak milik. Hak milik merupakan hak pangkal (originair recht). Adanya hak milik dapat menimbulkan hakhak lainnya yang merupakan hak turunan (afgeleide rechten).

Apabila hal tersebut dilihat dalam perspektif teori Grotius maka urgensi perjanjian (kontrak) berupa PSP dari sumber BBT gigi asli adalah untuk melindungi hak milik manusia sumber BBT gigi asli tersebut. Menurut teori ini BBT gigi asli merupakan suum karena pada BBT gigi asli tersebut merupakan anggota tubuh sumber BBT. Maka dari itu menurut hukum alam, BBT gigi asli sebagai suum harus dilindungi, dihargai, dan dijamin. Hal tersebut menimbulkan konsekuensi bahwa apabila BBT gigi asli yang telah dikumpulkan beralih begitu saja kepemilikannnya menjadi milik lembaga kesehatan dan penelitian maka sama halnya hal itu seperti merenggut hak milik sumber BBT dan merupakan ketidakadilan. Hak milik manusia 
sumber BBT dipandang sebagai hak eksklusif yang mengandung pengertian bahwa pemilik BBT tersebut memiliki kekuasaan untuk mempertahankan dan menggunakannya secara eksklusif dengan tidak memberi kemungkinan bagi pihak lain, baik itu tenaga kesehatan atau peneliti, untuk menuntut hak yang sama atas BBT tersebut.

Hak milik sebagai suatu hak kebendaan yang diatur dalam Kitab Undang-Undang Hukum Perdata (KUH Perdata) dipahami sebagai hak absolut dan merupakan hak induk serta merupakan sumber dari pemilikan seperti dalam Pasal 570 KUH Perdata. Konsep hak milik yang dimaksud hanya meliputi hak milik atas benda bergerak dan benda tidak bergerak yang bukan tanah (Meliala, 2015). Benda bergerak menurut sifatnya adalah benda yang dapat dipindahkan. Sementara itu, benda tidak bergerak menurut sifatnya adalah benda yang tidak dapat dipindahkan (Abdul Kadir, 2014). Didasarkan pada rumusan tersebut maka BBT gigi asli telah terpisah dari tubuh pasien melalui proses pencabutan dipandang sebagai benda bergerak. Hal tersebut dikarenakan BBT gigi asli tersebut dapat dipindahkan, dalam hal ini dari pasien dipindahtangankan kepada tenaga kesehatan lalu dipindahtangankan kepada fasilitas kesehatan dan insitusi pendidikan kedokteran gigi.

Adanya hak milik atas suatu benda menjadikan pemilik dapat mengambil manfaat maksimal atas benda yang dimilikinya tersebut. Ketika gigi-gigi asli yang masih berupa organ tubuh yang menempel pada tubuh pasien, pasien sebagai pemilik gigi tersebut dapat mengambil manfaat dari gigi-gigi tersebut. Adapun manfaat yang dimaksud adalah untuk membantu proses pengunyahan makanan (mastikasi) dan melafalkan kata-kata bahkan untuk menjaga penampilan, khususnya pada gigi-gigi bagian depan yang terlihat. Namun, ketika gigi-gigi tersebut telah dicabut dan terpisah dari tubuhnya maka pasien dianggap tidak lagi dapat mengambil manfaat dari gigi-gigi yang telah dicabut tersebut karena sudah tidak lagi dapat digunakan 
untuk menjalankan fungsi-fungsi yang telah dinyatakan sebelumnya. Dengan demikian, ketika gigi-gigi tersebut telah menjadi BBT maka pasien tidak lagi dapat mengambil manfaat dari gigi-gigi tersebut. Meski demikian, BBT gigi asli tersebut masih merupakan hak milik pasien.

Pemilik benda dengan hak miliknya mempunyai hak untuk menguasai benda tersebut dengan sebebas-bebasnya. Hal tersebut meliputi hak untuk memelihara benda tersebut sebaik-baiknya, membebani dengan hak-hak kebendaan tertentu, memindahtangankan, mengubah bentuk, bahkan melenyapkan. Pasien sebagai pemilik BBT gigi asli memiliki kuasa untuk melakukan apapun terhadap BBT gigi asli yang berasal dari dirinya. Kuasa tersebut dapat berupa menyimpan kembali gigi yang telah dicabut. Selain itu, pasien juga memiliki hak untuk memindahtangankan BBT gigi asli miliknya tersebut kepada tenaga kesehatan untuk kemudian diserahkan lagi kepada institusi pendidikan kedokteran gigi untuk kemudian digunakan dalam pendidikan dan penelitian. Bahkan pasien juga memiliki hak untuk menolak menyerahkan BBT gigi asli tersebut kepada lembaga kesehatan, pendidikan, dan penelitian lalu membuang ataupun melenyapkan BBT gigi asli tersebut.

Hak milik merupakan "droit inviolable et sacre" yang artinya merupakan hak yang tidak bisa diganggu-gugat, baik oleh orang lain maupun penguasa. Dalam hal kepemilikan BBT gigi asli, pasien mempunyai hak milik yang tidak dapat diganggu-gugat atas BBT gigi asli. Hak milik yang dimiliki pasien atas BBT gigi asli tersebut tidak dapat diintervensi oleh kepentingan pendidikan dan penelitian dari institusi pendidikan kedokteran gigi. Walaupun kepentingan-kepentingan tersebut ditujukan untuk hal yang baik sekalipun tetap saja hak milik pasien atas BBT gigi asli tersebut tidak dapat dikesampingkan. Andaipun gigi-gigi asli tersebut dibutuhkan untuk alasan pendidikan dan pengembangan ilmu pengetahuan serta teknologi maka 
penyerahan BBT gigi asli untuk kepentingan tersebut didasarkan atas kesukeralaan dari pasien sebagai pemilik. Penyerahan BBT itu pun baru dapat dikatakan sukarela ketika pasien sebagai sumber BBT gigi asli memberikan persetujuan atas pemanfaatan BBT setelah mendapatkan penjelasan lengkap.

Hak milik, termasuk hak milik atas BBT gigi asli, dilindungi oleh gugat yang disebut sebagai Revindicatie yang ditujukan untuk mempertahankan hak milik itu. Perlindungan atas hak milik melalui gugat Revindicatie diatur di dalam Pasal 574 KUH Perdata yang menyatakan bahwa tiap-tiap pemilik suatu kebendaan, berhak menuntut kepada siapa pun juga yang menguasainya, akan pengembalian kebendaan itu dalam keadaan beradanya.

Menurut Hukum Acara Untuk melakukan gugat Revindicatie pemilik dapat meminta pada hakim agar barangnya disita. Penyitaan tersebut disebut sebagai revindicatoir beslag (Pasal 226 HIR). Hak gugat Revindicatie hanya ada pada pemilik dan tidak ada pada orang yang masih akan menjadi pemilik.

Dengan demikian, ketika BBT berupa gigi-gigi asli dikumpulkan di fasilitas kesehatan gigi lalu kemudian diserahkan kepada mahasiswa yang membutuhkan untuk kemudian digunakan oleh institusi pendidikan kedokteran gigi untuk kepentingan pendidikan dan penelitian tanpa persetujuan dari pasien pemilik BBT gigi asli, maka menurut Pasal 574 KUH Perdata pasien pemilik sah BBT gigi asli tersebut dapat mengajukan gugatan melalui hakim terhadap fasilitas kesehatan gigi, mahasiswa, dan institusi pendidikan kedokteran gigi. Menurut hukum acara di dalam Pasal 226 HIR pasien sebagai pemilik dapat meminta kepada hakin untuk melakukan penyitaan (revindicatoir beslag) BBT gigi asli miliknya tersebut.

Berdasarkan ketentuan di dalam Pasal 584 KUH Perdata dinyatakan bahwa hak milik atas sesuatu kebendaan tidak dapat diperoleh dengan cara lain, melainkan dengan pemilikan, karena perlekatan, karena daluwarsa, karena pewarisan, baik 
menurut undang-undang maupun menurut surat wasiat, dan karena penunjukan atau penyerahan berdasar atas suatu peristiwa perdata untuk memindahkan hak milik, dilakukan oleh orang yang berhak berbuat bebas terhadap kebendaan itu.

$$
\text { Sebelum menjelaskan }
$$
bagaimana fasilitas kesehatan gigi, mahasiswa, dan institusi pendidikan kedokteran gigi memperoleh hak milik atas BBT gigi asli perlu dipahami terlebih dahulu bagaimanakah pasien memperoleh hak miliknya atas gigi-gigi aslinya tersebut.

Salah satu cara untuk memperoleh hak milik adalah dengan melalui perlekatan. Perlekatan (natrekking), yaitu suatu cara memperoleh hak milik, dimana benda itu bertambah besar atau berlipat ganda karena alam (Salim, 2003). Sementara itu, untuk membentuk organ gigi manusia sel mengalami pertumbuhan dan perkembangan dalam periode waktu tertentu hingga akhirnya gigi tumbuh (erupsi) pada rongga mulut manusia.
Dalam hal ini gigi manusia berkembang dari unsur ektoderm dan mesoderm. Email gigi dibentuk oleh sel ameloblas. Email terletak di atas selapis dentin yang tebal yang dihasilkan oleh sel odontoblas, suatu derivat krista neuralis. Cementum dibentuk oleh sementoblas, derivat dari sel mesenkim lain yang ditemukan dalam akar gigi. Gigigigi pertama (gigi desidua atau gigi susu) muncul 6 hingga 24 bulan setelah lahir. Sementara itu, gigi tetap yang tumbuh pasca lahir dibentuk dimulai sejak perkembangan bulan ketiga.

Hal tersebut menunjukkan bahwa pertumbuhan dan perkembangan gigi asli tersebut merupakan proses alami yang terjadi di dalam tubuh manusia. Dengan demikian, apabila dikaitkan dengan cara memperoleh hak milik maka dapat dikatakan bahwa pasien memperoleh hak milik atas gigi-gigi aslinya tersebut melalui perlekatan (natrekking).

\section{Pengaturan Hukum Di Masa} Yang Akan Datang Terhadap Penggunaan Bahan Biologis 
Tersimpan

Tanpa

\section{Persetujuan Pemiliknya}

Pelanggaran terhadap pedoman etik pemanfaatan pada praktek pemanfaatan BBT dalam pendidikan dan penelitian kedokteran gigi ternyata juga menimbulkan permasalahan terhadap ketentuanketentuan hukum yang berlaku. Dalam hal penggunaan BBT gigi asli untuk penelitian kedokteran gigi apabila dilakukan tanpa PSP dari pasien sebagai sumber BBT gigi asli atau tanpa mendapatkan perkecualian (waiver) dari KEPK institusional maka hal tersebut melanggar ketentuan yang diatur di dalam Pasal 44 ayat 3 Undang-Undang Nomor 36 Tahun 2009 yang mengatur tentang PSP dari calon subjek penelitian.

Selain itu, hal tersebut juga menimbulkan pelanggaran terhadap ketentuan di dalam Pasal 8 Peraturan Pemerintah Nomor 39 Tahun 1995 dan Pasal 2 Keputusan Menteri Kesehatan Nomor 1333 Tahun 2002 yang juga mengatur ketentuan mengenai pelaksanaan PSP dari calon subjek penelitian.

Tindakan komersialisasi BBT gigi asli dalam prosedur pengumpulannya juga menimbulkan pelanggaran terhadap ketentuan dalam Pasal 64 ayat 3 UndangUndang Nomor 36 Tahun 2009 yang menyatakan bahwa organ dan/atau jaringan tubuh dilarang diperjualbelikan dengan dalih apapun. Selain itu, adanya komerisalisasi BBT gigi asli yang bersumber dari jenazah juga menimbulkan permasalahan hukum karena hal tersebut bertentangan dengan ketentuan di dalam Pasal 17 Peraturan Pemerintah Republik Indonesia Nomor 18 Tahun 1981 Tentang Bedah Mayat Klinis Dan Bedah Mayat Anatomis Serta Transplantasi Alat Dan Atau Jaringan Tubuh Manusia. Pasal 17 PP Nomor 18 Tahun 1981 mengatur bahwa alat dan/atau jaringan tubuh manusia dilarang untuk diperjualbelikan.

Masih adanya ketidaksesuaian antara praktek pengunaan BBT dalam pendidikan dan penelitan kedokteran gigi dengan pedoman etik pemanfaatan BBT dan ketentuanketentuan hukum yang berlaku disebabkan oleh beberapa hal. Apabila ditinjau dari pedoman etik pemanfaatan BBT yang telah ditetapkan maka dapat dikatakan 
bahwa pedoman tersebut hanya bersifat memberikan petunjuk moral dan bukan merupakan suatu perintah. Pedoman tersebut juga tidak memiliki kekuatan seperti peraturan hukum yang dapat memaksa dan mengandung sanksi yang jelas apabila ketentuan di dalam pedoman etik penggunaan BBT tersebut dilanggar. Hal tersebut sesuai dengan apa yang dikemukakan oleh K. Bertens bahwa moral yang tidak dilembagakan sebagai hukum di tengah masyarakat hanya akan menjadi angan-angan belaka (Bertens, 2011). Oleh karena itu, pengaturan penggunaan BBT melalui pedoman etik pemanfaatan BBT, baik untuk kepentingan pendidikan atau penelitian, masih memiliki kekurangan dan masih dinilai lemah.

Permasalahan-permasalahan lain praktek penggunaan BBT dalam pendidikan dan penelitian kedokteran gigi juga ditemukan pada aspek yuridis. Ketentuan pada Pasal 44 Undang-Undang Nomor 36 Tahun 2009 terkait pelaksanaan penelitian kesehatan yang melibatkan manusia nampaknya masih ditafsirkan secara sempit. Penafsiran sempit tersebut tampak dari adanya pemahaman bahwa pelaksanaan PSP hanya dapat diterapkan sebatas pada manusia yang menjadi subjek penelitian tapi tidak berlaku untuk subjek manusia pemilik bagian tubuh (BBT) yang akan dimanfaatkan dalam sebuah penelitian.

Apabila ditinjau secara filosofis melalui pandangan personalistik maka seharusnya dapat dipahami bahwa tubuh dan jiwa manusia merupakan dua hal yang tidak terpisah sehingga BBT gigi asli yang merupakan bagian dari tubuh manusia dianggap merupakan bagian dari diri manusia itu sendiri. Sementara itu, jiwa manusia adalah meliputi kepribadian dan kehidupan manusia yang di dalamnya mencakup nilai intrinsik manusia, yaitu martabat manusia. Segala macam bentuk tindakan yang dilakukan terhadap bagian tubuh manusia tersebut sama artinya tindakan tersebut dilakukan terhadap diri manusia itu.

Dengan demikian, penelitian menggunakan BBT gigi asli tanpa persetujuan pemilik BBT gigi asli tersebut sama artinya dengan tindakan tersebut merendahkan martabat 
manusia pemilik BBT gigi asli tersebut.

Permasalahan yang sama juga terjadi pada ketentuan di dalam Pasal 64 ayat 3 Undang-Undang Nomor 36 Tahun 2009 yang ditafsirkan hanya terbatas untuk masalah transplantasi organ dan tidak berlaku untuk masalah donor organ tubuh untuk dijadikan sebagai BBT bagi kepentingan pendidikan dan penelitian. Kemudian pada Pasal 17 Peraturan Pemerintah Nomor 18 Tahun 1981 yang masih ditafsirkan secara sempit, dalam artian hanya larangan komersialisasi organ tubuh hanya berlaku untuk kasus transplantasi alat dan jaringan tubuh yang bersumber dari mayat.

Permasalahan lainnya juga timbul apabila ketetentuan di dalam Pasal Pasal 64 ayat 3 Undang-Undang Nomor 36 Tahun 2009 dibenturkan dengan Pasal 19 Peraturan Pemerintah Nomor 18 Tahun 1981 yang menyatakan bahwa larangan sebagaimana dimaksud dalam Pasal 17 dan Pasal 18 tidak berlaku untuk keperluan penelitian ilmiah dan keperluan lain yang ditetapkan oleh Menteri Kesehatan. Apabila mendasarkan kembali kepada aspek filosofis dari pandangan personalistik maka tindakan melakukan komersialisasi terhadap salah satu bagian tubuh manusia sama halnya dengan melakukan perdagangan manusia. Dengan demikian, komersialisasi organ tubuh manusia, termasuk itu BBT gigi asli, merupakan perbuatan yang merendahkan martabat manusia.

Pembaharuan terhadap ketentuan hukum pemanfaatan BBT ditujukan untuk mengatur penggunaan BBT dalam pendidikan dan penelitian kesehatan di Indonesia. Dengan demikian, pembaruan terhadap ketentuan hukum pemanfaatan BBT merupakan salah bentuk politik hukum nasional. Adapun politik hukum nasional merupakan perwujudan dari sistem hukum nasional yang berdasarkan Pancasila dan UndangUndang Dasar 1945. Pancasila sebagai nilai-nilai berkehidupan kebangsaan yang dicita-citakan di dalamnya mengandung keseimbangan nilai moral religius.

Pewasiatan organ tubuh untuk digunakan sebagai BBT ini 
merupakan pernyataan kehendak seseorang mengenai apa yang akan dilakukan terhadap tubuh organ tertentu miliknya, dalam hal ini gigigigi asli, kelak setelah orang tersebut meninggal dunia. Pelaksanaan wasiat tersebut dilakukan melalui pengambilan organ tubuh tersebut dilakukan setelah pewasiat meninggal dunia dan kemudian digunakan sebagai BBT.

Pewasiat organ tubuh sebagai BBT tersebut dilakukan secara sukarela dengan menyerahkan organ tubuh kepada pihak-pihak yang membutuhkan untuk digunakan dalam pendidikan dan pengembangan ilmu pengetahuan. Dengan demikian, pewasiat tersebut mewasiatkan sesuatu hal yang berwujud materi yaitu berupa organ tubuh (gigi asli) dan ditujukan untuk memberikan manfaat yaitu dimanfaatkan sebagai BBT yang kemudian digunakan untuk pengembangan ilmu pengerahuan dan teknologi di bidang kedokteran gigi.

\section{SIMPULAN}

1. Berdasarkan refleksi dari teori hukum alam mengenai hak milik dan teori metafisik maka
BBT gigi asli merupakan hak milik pasien sehingga hak milik pasien atas BBT gigi asli tersebut harus dilindungi oleh hukum.

2. Dua pengaturan hukum di masa yang akan datang yang dapat dilakukan terkait penggunaan bahan biologis tersimpan tanpa persetujuan pemiliknya adalah berupa peraturan hukum mengenai pewasiatan organ tubuh jenazah untuk dimanfaatkan sebagai BBT dan peraturan hukum mengenai kewajiban pelaksanaan Persetujuan Setelah Penjelasan (PSP) dalam pemanfaatan organ tubuh manusia sebagai BBT.

\section{SARAN}

1. Perlu dilakukan perumusan di dalam Kitab Undang-Undang Hukum Perdata terkait aspek kepemilikan organ tubuh manusia.

2. Perlu dilakukan pembaharuan peraturan hukum baik itu di dalam Undang-Undang Kesehatan, Undang-Undang Pendidikan Kedokteran dan 
Peraturan Pemerintah mengenai penelitian dan pengembangan kesehatan terkait pengaturan pemanfaatan Bahan Biologis Tersimpan (BBT) dalam pendidikan dan penelitian di bidang kesehatan.

\section{DAFTAR PUSTAKA}

Abdul Kadir, Pengenalan Sistem Informasi, Edisi Revisi, Andi, Yogyakarta, 2014.

Djaja S. Meliala, Perkembangan Hukum Perdata Tentang Benda dan Hukum Perikatan, Nuansa Aulia, Bandung, 2015.

Elaine Fernades Felipe, Ethical Aspect Of Teeth Obtained By Odontology Graduates, Rev. bioét. (Impr.), Vol. 22, No. 1, 2014.

H.S. Salim, Pengantar Hukum Perdata Tertulis, Sinar Grafika, Jakarta, 2003.

K. Bertens, Etika, Edisi Revisi, Kanisius, Yogyakarta, 2013.
Roscoe Pound, Pengantar Filsafat Hukum, Bhratara, Jakarta, 1972.

Silvia Helena de Carvalho Sales Peres, Student's And General Population Knowledge About The Use and Commerce of Human Teeth, Rev Gaucha Odontol, Vol. 60, No. 1, 2012.

Undang-Undang Dasar 1945.

Undang-Undang Nomor 23 Tahun 1992 Tentang Kesehatan.

Undang-Undang Nomor 39 Tahun 1999 Tentang Hak Asasi Manusia.

Undang-Undang Nomor 18 Tahun 2002 Tentang Sistem Nasional Penelitian, Pengembangan, Dan Penerapan Ilmu Pengetahuan Dan Teknologi.

Undang-Undang Nomor 29 tahun 2004 Tentang Praktek Kedokteran.

Undang-Undang Nomor 36 Tahun 2009 Tentang Kesehatan.

Undang-Undang Nomor 20 Tahun 2013 Tentang Pendidikan Kedokteran. 